\title{
Aerobic Growth of Campylobacter sputorum subspecies bubulus with Formate
}

\author{
By HUBERT G. D. NIEKUS, * ELS VAN DOORN, \\ WYTSKE DE VRIES AND ADRIAN H. STOUTHAMER \\ Department of Microbiology, Biological Laboratory, Free University, De Boelelaan 1087, \\ 1007 MC Amsterdam, The Netherlands
}

(Received 27 July 1979; revised 17 December 1979)

\begin{abstract}
Formate stimulated growth of the microaerophilic bacterium Campylobacter sputorum subsp. bubulus at reduced dissolved oxygen tensions (d.o.t.). At a d.o.t. of $2 \mathrm{kPa}$ the mean doubling time of $C$. sputorum growing in a complex medium supplemented with formate was $2 \mathrm{~h}$. Growth did not occur in the absence of $\mathrm{O}_{2}$. When $C$. sputorum was cultured in a complex medium with formate, growth and formate consumption slowed down after a rise of the d.o.t. from 2 to $15 \mathrm{kPa}$. At the same time the potential respiration rate diminished greatly. The effects of exposure to a d.o.t. of $15 \mathrm{kPa}$ could still be reversed after $4 \mathrm{~h}$ by shifting the d.o.t. back to $2 \mathrm{kPa}$. The decrease in the potential respiration rate could be related to a loss of formate dehydrogenase activity. Its susceptibility to a high d.o.t. was greater when formate was present in the growth medium than in its absence. Formate oxidase had a low affinity for $\mathrm{O}_{2}$ and $\mathrm{H}_{2} \mathrm{O}_{2}$ was a product of the oxidation of formate by $\mathrm{O}_{2}$. Formate dehydrogenase appeared to be a membrane-bound enzyme. Of the possible physiological electron acceptors tested, only FAD gave rise to a detectable, although low, activity of formate dehydrogenase. Campylobacter sputorum grown in the complex medium with formate contained cytochromes of the $b$ - and $c$-type. Cytochrome $b$ was membrane-bound; cytochrome $c$ was largely recovered in the soluble fraction. A CO-binding pigment was identified as a cytochrome of the $c$-type. Campylobacter sputorum possessed cytochrome $c$ peroxidase activity. Cytochrome oxidases of a known type could not be detected unequivocally in a (reducedplus-CO minus reduced) difference spectrum. An important role in the microaerophilic nature of $C$. sputorum is ascribed to $\mathrm{H}_{2} \mathrm{O}_{2}$.
\end{abstract}

\section{INTRODUCTION}

Campylobacter sputorum subsp. bubulus is a microaerophilic vibrio which is unable to ferment carbohydrates (Loesche et al., 1965; Stouthamer et al., 1979). During aerobic growth the organism can use L-lactate as energy source if the dissolved oxygen tension (d.o.t.) is maintained at a low value (Niekus et al., 1977). Continuous culture experiments showed that formate was another, albeit less efficient, energy source for $C$. sputorum in the presence of limiting amounts of $\mathrm{O}_{2}$ (de Vries et al., 1980). Organisms from a medium containing L-lactate consumed $\mathrm{O}_{2}$ with the following electron donors: L-lactate, D-lactate, succinate, formate, NADH and NADPH. The activity with formate as substrate was by far the greatest and $\mathrm{H}_{2} \mathrm{O}_{2}$ was a product of formate oxidation (Niekus et al., 1978). This was interesting since $C$. sputorum differs from other Campylobacter species by being catalase-negative (Smibert, 1978). Evidence was obtained that C. sputorum subsp. bubulus disposes of $\mathrm{H}_{2} \mathrm{O}_{2}$ by means of a cytochrome $c$ peroxidase. A scheme depicting formate oxidation and $\mathrm{H}_{2} \mathrm{O}_{2}$ 
elimination by $C$. sputorum was proposed by Niekus et al. (1978). It is like the one described for the anaerobe Vibrio succinogenes (Jacobs \& Wolin, 1963):

$$
\begin{aligned}
\text { Formate }+\mathrm{O}_{2} & \rightarrow \mathrm{CO}_{2}+\mathrm{H}_{2} \mathrm{O}_{2} \\
\text { Formate }+2 \text { Cytochrome } c_{\mathrm{os}} & \rightarrow \mathrm{CO}_{2}+2 \text { Cytochrome } c_{\text {red }}+2 \mathrm{H}^{+} \\
2 \text { Cytochrome } c_{\text {red }}+2 \mathrm{H}^{+}+\mathrm{H}_{2} \mathrm{O}_{2} & \rightarrow 2 \text { Cytochrome } c_{\mathrm{ox}}+2 \mathrm{H}_{2} \mathrm{O} \\
\text { or } 2 \text { Cytochrome } c_{\text {red }}+2 \mathrm{H}^{+}+\frac{1}{2} \mathrm{O}_{2} & \rightarrow 2 \text { Cytochrome } c_{\mathrm{ox}}+\mathrm{H}_{2} \mathrm{O}
\end{aligned}
$$

The presence of formate oxidase in cells grown on lactate prompted us to study the role of formate in the energy metabolism of $C$. sputorum. In the present paper we describe the growth enhancement by formate at a reduced d.o.t. and its influence on the oxygen sensitivity of C. sputorum subsp. bubulus.

\section{METHODS}

Organism and growth conditions. Campylobacter sputorum subsp. bubulus strain 9977 (Loesche et al., 1965) was maintained as described previously (Niekus et al., 1977). Batch cultures were grown in a 21 or 71 fermenter with d.o.t., $\mathrm{pH}$ and temperature control. The d.o.t. was measured with a sterilizable oxygen electrode (types MG2 and G2L; Biolafitte, France) which was calibrated in air-saturated growth medium (d.o.t. = $0.21 \mathrm{~atm}=21 \mathrm{kPa})$. The output signal of the electrode in uninoculated medium was stable within $\pm 0 \cdot 2 \mathrm{kPa}$ for $24 \mathrm{~h}$. The signal was amplified and fed to a PI-control unit (type 6475; Samson, Germany) which affected the potentiometer of a motor control unit. This unit controlled the agitation speed in the fermenter, keeping fluctuations of the d.o.t. within $\pm 0.2 \mathrm{kPa}$. Before inoculating the medium it was sparged with $\mathrm{N}_{2}$ until anaerobic conditions were attained. During growth, $\mathrm{O}_{2}$ was supplied by slowly bubbling air through the medium ( 1 to $51 \mathrm{~h}^{-1}$, depending on the size of the culture). The pressure of the inflowing air was stabilized by means of a back pressure regulator and a differential pressure regulator. The $\mathrm{pH}$ was controlled at $6 \cdot 8 \pm$ 0.05 by adding small portions of $1.0 \mathrm{M}-\mathrm{HCl}$. The growth temperature was $37 \pm 0.2{ }^{\circ} \mathrm{C}$. The basal growth medium (T) contained (per litre) $26 \mathrm{~g}$ tryptose broth, $1 \mathrm{~g} \mathrm{MgCl}_{2} \cdot 6 \mathrm{H}_{2} \mathrm{O}$ and $10 \mathrm{mg} \mathrm{FeCl}_{3} \cdot 6 \mathrm{H}_{2} \mathrm{O}$ supplemented with $0.01 \mathrm{M}$-sodium/potassium phosphate buffer $(\mathrm{pH} 6.8)$ which was sterilized separately. Where indicated, $3 \mathrm{~g}$ sodium formate or $3 \mathrm{~g}$ sodium DL-lactate solution $[60 \%(\mathrm{w} / \mathrm{w})$ sodium $\mathrm{L}$-lactate and $6 \%(\mathrm{w} / \mathrm{w})$ sodium D-lactate] were added (media TF and TL, respectively). The inoculum was a culture of $C$. sputorum grown in TL medium supplemented with $1 \mathrm{~g} \mathrm{KNO}_{3} \mathrm{I}^{-1}$ at $37^{\circ} \mathrm{C}$ for $40 \mathrm{~h}$ in an anaerobic jar containing an atmosphere of $\mathrm{N}_{2}$ plus $5 \% \mathrm{CO}_{2}$. Growth was measured turbidimetrically at $660 \mathrm{~nm}\left(A_{660}\right)$ with a Pye Unicam SP6-300 spectrophotometer. The relation between dry weight of bacteria and $A_{660}$ was fairly constant: dry weight $\left(\mathrm{mg} \mathrm{ml}^{-1}\right)=A_{660} \times 0.63( \pm 0.04)$.

Analytical procedures. Formate was measured according to Lang \& Lang (1972). Protein was measured by Lowry's Folin procedure using bovine serum albumin as a standard.

Preparation of cell suspensions and extracts. Suspensions and extracts were prepared as described earlier (Niekus et al., 1978). The washing buffer ( $\mathrm{pH} 7 \cdot 2$ ) consisted of $0 \cdot 1$ m-potassium phosphate, 5 mm-EDTA, $1 \mathrm{mM}^{-\mathrm{MgCl}_{2}}$ and $0 \cdot 1 \mathrm{~mm}$-dithioerythritol. Precautions were taken throughout the procedures to maintain anaerobic conditions. Extracts were divided into small portions and stored in liquid nitrogen. When needed for an assay, a portion was thawed and stored in ice, while a stream of $\mathrm{N}_{2}$ gas was passed over its surface.

Measurement of enzyme activities. Oxygen consumption was followed polarographically in the biological oxygen monitor, model 53 (Yellow Springs Instrument Co., Yellow Springs, Ohio, U.S.A.). The potential respiration rate of bacteria growing in TF medium was determined by the following procedure. Samples were taken from the culture and, after measuring the $A_{660}$, they were quickly diluted in $0 \cdot 1 \mathrm{M}$-potassium phosphate buffer ( $\mathrm{pH} 7 \cdot 2$ ). Immediately thereafter the $\mathrm{O}_{2}$ consumption rate in the presence of sodium formate (final concentration $10 \mathrm{~mm}$ ) was measured at $37^{\circ} \mathrm{C}$. The respiratory activity of cells growing in $\mathrm{T}$ medium was determined both in the absence and presence of formate. Activity was expressed as nmol $\mathrm{O}_{2}$ consumed $\mathrm{min}^{-1}(\mathrm{mg} \text { dry } \mathrm{wt})^{-1}$. All other enzyme activities were determined at $25^{\circ} \mathrm{C}$. Oxygen consumption by cell suspensions or extracts was measured using the following substrates (final concentrations): formate (10 mM), L-lactate $(10 \mathrm{mM})$, potassium ascorbate $(1.5 \mathrm{~mm})$ and potassium ascorbate $(1.5 \mathrm{~mm})$ plus $N, N, N^{\prime}, N^{\prime}$-tetramethyl-p-phenylenediamine dihydrochloride (TMPD, $0.25 \mathrm{~mm}$ ). The oxidation of NADH or NADPH $(0.14 \mathrm{~mm})$ by extracts was measured spectrophotometrically from the decrease in absorbance at $339 \mathrm{~nm}$; separate experiments in the oxygen monitor showed that $\mathrm{O}_{2}$ was used as an acceptor in the aerobic oxidation of NAD(P)H. From the stimulation of these activities by the addition of $1.0 \mathrm{~mm}-\mathrm{H}_{2} \mathrm{O}_{2}, \mathrm{NADH}$ and NADPH peroxidase activities, respectively, were determined. $\mathrm{H}_{2} \mathrm{O}_{2}$ formation by cell suspensions in the presence of formate was measured according to Niekus et al. (1978). 


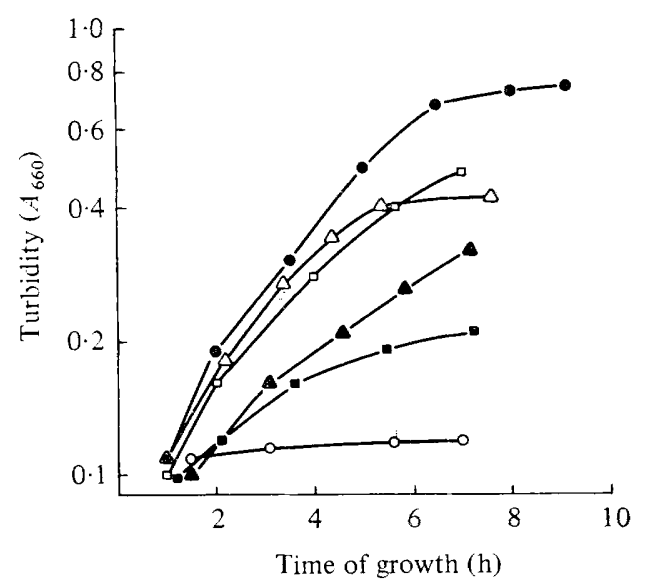

Fig. 1. Growth of $C$. sputorum subsp. bubulus at different dissolved oxygen tensions in the presence or absence of formate. Oxygen tension/medium:, $2 \mathrm{kPa} / \mathrm{TF} ; \square, 10 \mathrm{kPa} / \mathrm{TF} ; \mathbf{a}, 15 \mathrm{kPa} / \mathrm{TF}$; $\Delta, 2 \mathrm{kPa} / \mathrm{T} ; \Delta, 10 \mathrm{kPa} / \mathrm{T}$. In one experiment TF medium was sparged with $\mathrm{N}_{2}$ instead of air $(\mathrm{O})$.

Formate dehydrogenase was assayed spectrophotometrically in a reaction mixture containing potassium phosphate buffer $(50 \mathrm{~mm}, \mathrm{pH} 7 \cdot 0)$, formate $(5 \mathrm{~mm})$, EDTA $(0.4 \mathrm{~mm})$, extract and an electron acceptor. The following acceptors were used: 1.2 mM-NAD or NADP $\left(339 \mathrm{~nm}, \epsilon=6.31 \mathrm{mmol}^{-1} \mathrm{~cm}^{-1}\right) ; 0 \cdot 13 \mathrm{~mm}-\mathrm{FAD}$ $\left(450 \mathrm{~nm}, \epsilon=11.31 \mathrm{mmol}^{-1} \mathrm{~cm}^{-1}\right) ; 1.0 \mathrm{~mm}$-benzyl viologen $\left(600 \mathrm{~nm}, \epsilon=7.41 \mathrm{mmol}^{-1} \mathrm{~cm}^{-1}\right) ; 0.09 \mathrm{mM}-2,6-$ dichlorophenolindophenol (DCPIP) $\left(600 \mathrm{~nm}, \epsilon=211 \mathrm{mmol}^{-1} \mathrm{~cm}^{-1}\right)$; DCPIP plus $0.04 \%(\mathrm{w} / \mathrm{v})$ phenazine methosulphate (PMS) $(600 \mathrm{~nm}) ; 1.0 \mathrm{~mm}$-potassium ferricyanide $\left(420 \mathrm{~nm}, \epsilon=1.01 \mathrm{mmol}^{-1} \mathrm{~cm}^{-1}\right)$. The assays were carried out under anaerobic conditions except with DCPIP and ferricyanide as electron acceptors.

Cytochrome peroxidase (ferrocytochrome $c$ :hydrogen-peroxide oxidoreductase; EC 1.11.1.5) was assayed by the method of Ellfolk \& Soininen (1970). The assay mixture contained sodium phosphate buffer (20 mM, pH 7.2), ferrocytochrome $c$ (from horse heart, $0.013 \mathrm{~mm}$ ) and extract $\left(0.1\right.$ to $0.5 \mathrm{mg}$ protein $\mathrm{ml}^{-1}$ ). The oxidation of ferrocytochrome $c$ by oxygen was negligible even in the presence of extract. The reaction was started by adding $\mathrm{H}_{2} \mathrm{O}_{2}$ (final concentration $0.035 \mathrm{mM}$ ) and the initial decrease in absorbance at $550 \mathrm{~nm}$ was determined. A decrease in the $A_{550}$ of 0.021 corresponded to the oxidation of 1 nmol ferrocytochrome $c$ $\mathrm{ml}^{-1}$. Dithionite-reduced ferrocytochrome $c$ was prepared according to Yonetani \& Ray (1965).

Measurement of difference spectra and reduction kinetics of cytochrome $c$. Difference spectra were recorded as described previously (Niekus et al., 1977). The mean cytochrome content and the standard deviation were calculated from the results of at least four determinations in different batches. The reduction of cytochrome $c$ by extracts was followed with an Aminco DW-2 spectrophotometer set in the dual-wavelength mode using 552 and $538 \mathrm{~nm}$ as the sample and reference wavelengths, respectively. In experiments in which cytochrome $c$ reduction and oxygen consumption were followed simultaneously, a large cuvette $(7 \mathrm{ml})$ was used, which was covered by a Teflon stopper. A Clark-type electrode was fitted through a hole in the stopper and connected to the biological oxygen monitor. The contents of the cuvette were stirred by two magnetic cell stirrers. Additions were made with a syringe through a small hole in the stopper.

Chemicals. Tryptose broth was obtained from Difco; cytochrome $c$ (from horse heart, type III) and bovine blood superoxide dismutase (3000 $\mathrm{U} \mathrm{mg}^{-1}$; measured according to McCord \& Fridovich, 1969) were from Sigma; adenine nucleotides, cofactors and all other enzymes were from Boehringer.

\section{RESULTS}

\section{Growth at different dissolved oxygen tensions}

Campylobacter sputorum subsp. bubulus grows aerobically in tryptose medium without any additional energy source. However, the addition of L-lactate markedly increased the growth rate and yield (Niekus et al., 1977). Formate also stimulated growth of $C$. sputorum (Fig. 1) but not as effectively as lactate. The organism exhibited its microaerophilic character when grown in TF medium: growth at a d.o.t. of $2 \mathrm{kPa}$, diminished growth at a d.o.t. $\geqslant 10$ $\mathrm{kPa}$ and no growth in the absence of $\mathrm{O}_{2}$ (Fig. 1). The mean doubling time at a d.o.t. of $2 \mathrm{kPa}$ 


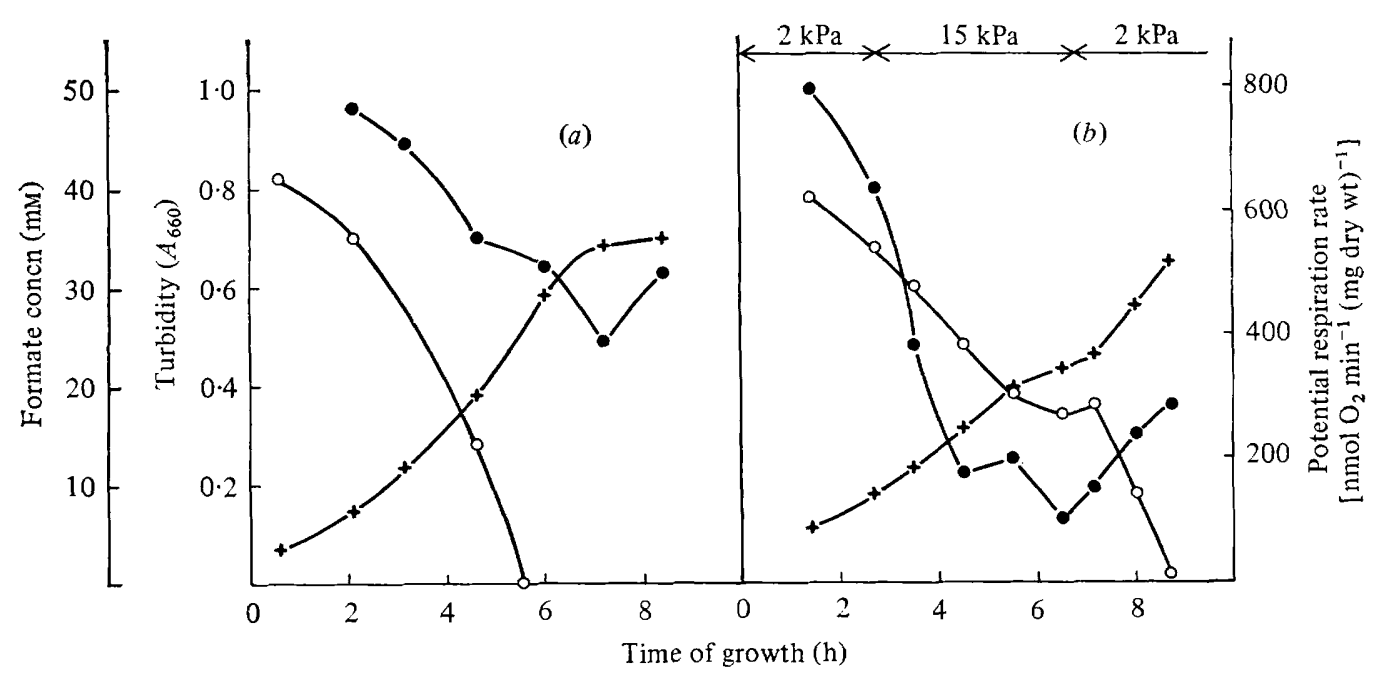

Fig. 2. Growth $(+)$, formate consumption $(\bigcirc)$ and potential respiration rate $(\odot)$ of $C$. sputorum subsp. bubulus in TF medium. The d.o.t. was kept constant at $2 \mathrm{kPa}(a)$ or temporarily increased to $15 \mathrm{kPa}(b)$.

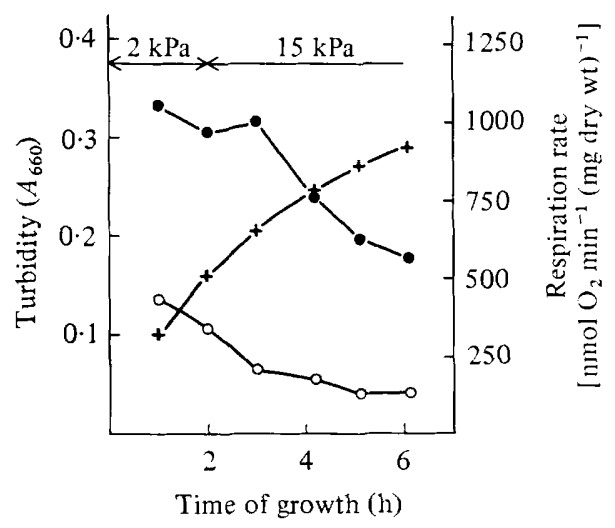

Fig. 3. Growth $(+)$ and respiratory activity in the absence $(O)$ or presence $(\bullet)$ of $10 \mathrm{~mm}$-formate. Campylobacter sputorum subsp. bubulus was cultured in T medium. The d.o.t. was kept constant at $2 \mathrm{kPa}$ for $2 \mathrm{~h}$ and then raised to $15 \mathrm{kPa}$.

was approximately $2 \mathrm{~h}$. When the d.o.t. was maintained below $0.2 \mathrm{kPa}$, C. sputorum still grew in TF medium at a rate comparable to that at a d.o.t. of $2 \mathrm{kPa}$. The culture turned dark-green at such a low oxygen tension but the green colour disappeared on raising the d.o.t. to $1 \mathrm{kPa}$. The colour change resulted from a dark deposit which interfered with the turbidity measurements. Its nature was not investigated further.

When C. sputorum was grown in TF medium at a d.o.t. of $2 \mathrm{kPa}$, formate (initial concentration approx. $40 \mathrm{~mm}$ ) was consumed in 5 to $6 \mathrm{~h}$ (Fig. $2 \mathrm{a}$ ). At a d.o.t. of $10 \mathrm{kPa}$ only $12 \mathrm{mM}$ formate was consumed after $7 \mathrm{~h}$ and at $15 \mathrm{kPa}$ formate was not used. When during growth the d.o.t. was raised from 2 to $15 \mathrm{kPa}$, growth and formate consumption slowed down (Fig. $2 b$ ). There was a concomitant sharp decrease in the potential respiration rate. After a period of $4 \mathrm{~h}$ the growth inhibitory effect of a high d.o.t. was reversible, because growth and formate consumption were restored by decreasing the d.o.t. to $2 \mathrm{kPa}$ (Fig. $2 b$ ). These events were accompanied by an increase in the potential respiration rate. Catalase $(35 \mu \mathrm{g}$ $\mathrm{ml}^{-1}$ ) or superoxide dismutase $\left(3 \mu \mathrm{g} \mathrm{ml}^{-1}\right)$ added to the growth medium $1 \mathrm{~h}$ before the shift 
Table 1. Enzyme activities in extracts of C. sputorum subsp. bubulus

Extracts were prepared from organisms grown in TF medium at a d.o.t. of $2 \mathrm{kPa}$ for $4 \mathrm{~h}$ or, in the case of the shift experiments, at a d.o.t. of $2 \mathrm{kPa}$ for $2 \mathrm{~h}$ followed by incubation at a d.o.t. of $15 \mathrm{kPa}$ for $3 \mathrm{~h}$. Enzyme activities were measured as described in Methods. The $\mathrm{O}_{2}$ consumption rates with formate and ascorbate-TMPD are expressed as nmol $\mathrm{O}_{2}$ consumed $\min ^{-1}$ (mg protein) ${ }^{-1}$. The other activities are expressed as nmol absorbing compound consumed or produced $\min ^{-1}$ (mg protein) $)^{-1}$.

Oxidase activity

\begin{tabular}{|c|c|c|c|c|}
\hline \multirow{2}{*}{$\begin{array}{l}\text { Growth } \\
\text { conditions }\end{array}$} & \multicolumn{4}{|c|}{ Electron donor } \\
\hline & Formate & Ascorbate-TMPD & NADH & NADPH \\
\hline No shift & 190 & 36 & $9 \cdot 0$ & $18 \cdot 8$ \\
\hline \multirow[t]{4}{*}{ Shift } & $11 \cdot 5$ & 19 & $5 \cdot 3$ & $17 \cdot 0$ \\
\hline & \multicolumn{4}{|c|}{ Peroxidase activity } \\
\hline & \multicolumn{4}{|c|}{ Electron donor } \\
\hline & NADH & NAD & & Ferrocytochrome $c$ \\
\hline \multirow{5}{*}{$\begin{array}{l}\text { No shift } \\
\text { Shift }\end{array}$} & 0.9 & $8 \cdot 9$ & & 52 \\
\hline & $0 \cdot 3$ & $5 \cdot 3$ & & 17 \\
\hline & \multicolumn{4}{|c|}{ Formate dehydrogenase activity } \\
\hline & \multicolumn{4}{|c|}{ Electron acceptor } \\
\hline & DCPIP & $\mathrm{K}_{3} \mathrm{Fe}(\mathrm{C}$ & & Benzyl viologen \\
\hline No shift & 235 & 480 & & 380 \\
\hline Shift & 16 & 32 & & ND \\
\hline
\end{tabular}

ND, Not determined.

to $15 \mathrm{kPa}$ could not prevent the detrimental effects of a high d.o.t. on growth, formate consumption and potential respiration rate (results not shown).

Growth in $\mathrm{T}$ medium was also diminished by raising the d.o.t. from 2 to $15 \mathrm{kPa}$ (compare Figs 1 and 3). The respiration rate of organisms taken from a culture of C. sputorum in $T$ medium was markedly stimulated by the addition of formate (Fig. 3). A rise of the d.o.t. in the absence of formate in the growth medium did not affect the formate oxidase activity as severely as it did in TF medium (compare Figs $2 b$ and 3 ).

Enzyme activities in cell suspensions and extracts

A washed suspension of cells, grown in TF medium at a d.o.t. of $2 \mathrm{kPa}$ for $4 \mathrm{~h}$, consumed $390 \mathrm{nmol} \mathrm{O}_{2} \min ^{-1}$ (mg protein) ${ }^{-1}$ and produced $355 \mathrm{nmol}_{2} \mathrm{O}_{2} \min ^{-1}$ (mg protein) ${ }^{-1}$ with formate as substrate. Formate oxidase was inhibited in the presence of 1 and $5 \mathrm{~mm}-$ $\mathrm{KCN}$ by 29 and $59 \%$, respectively, whereas 10 and 50 mm- $\mathrm{NaN}_{3}$ inhibited activity by 36 and $68 \%$, respectively; $\mathrm{H}_{2} \mathrm{O}_{2}(1 \cdot 3 \mathrm{~mm})$ inhibited activity by $55 \%$. The activities listed above were all measured in air-saturated buffer $\left(255 \mu \mathrm{M}-\mathrm{O}_{2}\right)$. When the initial $\mathrm{O}_{2}$ concentration in the assay mixture was lowered to $65 \mu \mathrm{M}-\mathrm{O}_{2}$, the $\mathrm{O}_{2}$ consumption rate in the presence of formate fell to approximately half the value measured at $255 \mu \mathrm{M}-\mathrm{O}_{2}$. This indicates that formate oxidase of C. sputorum has a low affinity for $\mathrm{O}_{2}$.

A cell-free extract consumed $\mathrm{O}_{2}$ with the following substrates: formate, $\mathrm{NADH}, \mathrm{NADPH}$, ascorbate plus TMPD (Table 1). TMPD caused only a small stimulation of the $\mathrm{O}_{2}$ consumption with ascorbate as substrate. L-Lactate was not a substrate.

$\mathrm{H}_{2} \mathrm{O}_{2}$ markedly stimulated the aerobic oxidation of NADPH by extracts of $C$. sputorum but only slightly increased NADH oxidation (Table 1). Peroxidase activity with dithionitereduced cytochrome $c$ from horse heart as electron donor was also observed (Table 1). Cytochrome $c$ peroxidase with a comparable activity was measured in extracts prepared from organisms grown in TL medium at a d.o.t. of $2 \mathrm{kPa}$ (result not shown). 


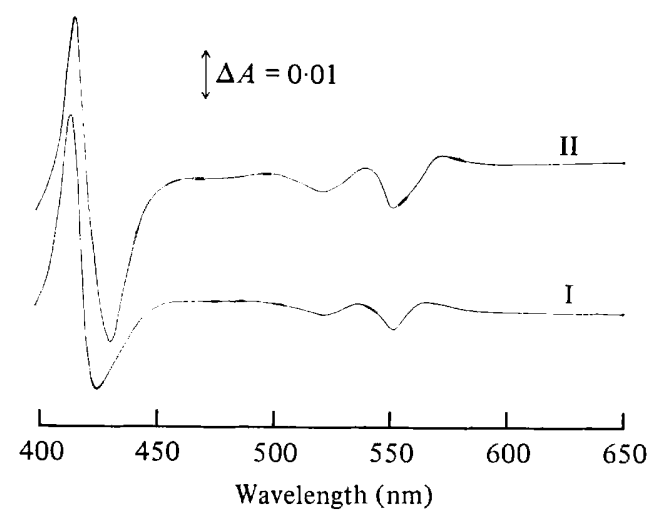

Fig. 4. (Reduced-plus-CO minus reduced) difference spectra of a supernatant fraction (I) and a pellet fraction (II) obtained after centrifuging an extract of C. sputorum subsp. bubulus at $140000 \mathrm{~g}$ for $1.5 \mathrm{~h}$. Organisms were grown in TF medium at a d.o.t. of $2 \mathrm{kPa}$. The supernatant fraction contained $1.6 \mathrm{mg}$ protein $\mathrm{ml}^{-1}$, the pellet fraction $2.6 \mathrm{mg}$ protein $\mathrm{ml}^{-1}$.

Formate dehydrogenase activity was detected in extracts of TF-grown organisms with DCPIP, ferricyanide or benzyl viologen as electron acceptors (Table 1). PMS stimulated the activity with DCPIP. NAD and NADP were inactive but low activity with FAD was observed $\left[4.0 \mathrm{nmol}\right.$ FAD reduced $\left.\min ^{-1}(\mathrm{mg} \text { protein })^{-1}\right]$ after a lag of several minutes. The lag phase was not caused by traces of $\mathrm{O}_{2}$ or $\mathrm{H}_{2} \mathrm{O}_{2}$, because the addition of an $\mathrm{O}_{2}-\mathrm{or}_{2} \mathrm{H}_{2} \mathrm{O}_{2}$ scavenging system to the reaction mixture had no effect (results not shown). When an extract was centrifuged at $140000 \mathrm{~g}$ for $1.5 \mathrm{~h}$ the formate dehydrogenase activity recovered was largely present in the pellet fraction $(90,90$ and $100 \%$ of the total activity with DCPIP, ferricyanide and FAD as electron acceptors, respectively).

Exposure of a batch culture in TF medium to a d.o.t. of $15 \mathrm{kPa}$ for $3 \mathrm{~h}$ caused a decrease of most activities measured in an extract (Table 1). NADPH oxidase was relatively insensitive to such a treatment while formate oxidase and dehydrogenase activities were most affected. These were reduced by 93 to $94 \%$ compared with the activities measured in extracts of organisms which had been grown in TF medium at a d.o.t. of $2 \mathrm{kPa}$ (Table 1).

\section{Cytochrome content}

The (dithionite-reduced minus air-oxidized) difference spectrum of TF-grown C. sputorum was similar to that reported for TL-grown organisms (Niekus et al., 1977). In spectra recorded at $25^{\circ} \mathrm{C}$, peaks were found at 552,522 and $424 \mathrm{~nm}$. A trough at $454 \mathrm{~nm}$ was indicative of the presence of flavins. The peaks were ascribed to cytochrome(s) $c$, but shoulders ascribed to cytochrome $b$ were also present. Using the absorption coefficient given by Kröger \& Innerhofer (1976) $\left[\Delta \epsilon(553-540)=25 \cdot 11 \mathrm{mmol}^{-1} \mathrm{~cm}^{-1}\right]$, the amount of cytochrome $c$ in organisms grown in TF medium at a d.o.t. of $2 \mathrm{kPa}$ was calculated to be $0.57 \pm 0.05 \mathrm{nmol}(\mathrm{mg} \text { protein })^{-1}$. After centrifuging extracts $(140000 \mathrm{~g}, 1.5 \mathrm{~h})$ cytochrome $c$ was recovered largely ( 70 to $80 \%$ ) in the supernatant fraction. The Soret peaks in difference spectra of the supernatant and pellet fractions were at 419 and $429 \mathrm{~nm}$, respectively. Moreover, the spectrum of the pellet fraction contained additional peaks at 558 and $529 \mathrm{~nm}$ of similar intensity to the $\alpha$ and $\beta$ peaks of cytochrome $c$. Therefore, cytochrome $b$ appeared to be membrane-bound.

(Reduced-plus-CO minus reduced) difference spectra of cell suspensions showed a major peak at $414 \mathrm{~nm}$ with a trough at $432 \mathrm{~nm}$. Most of this CO-binding pigment ( 70 to $75 \%$ ) was recovered in the supernatant fractions of extracts. The peak and the trough in the (reducedplus-CO minus reduced) difference spectrum of the supernatant fraction were found at 412 and $424 \mathrm{~nm}$, respectively, whereas the spectrum of the pellet fraction showed them at 413 


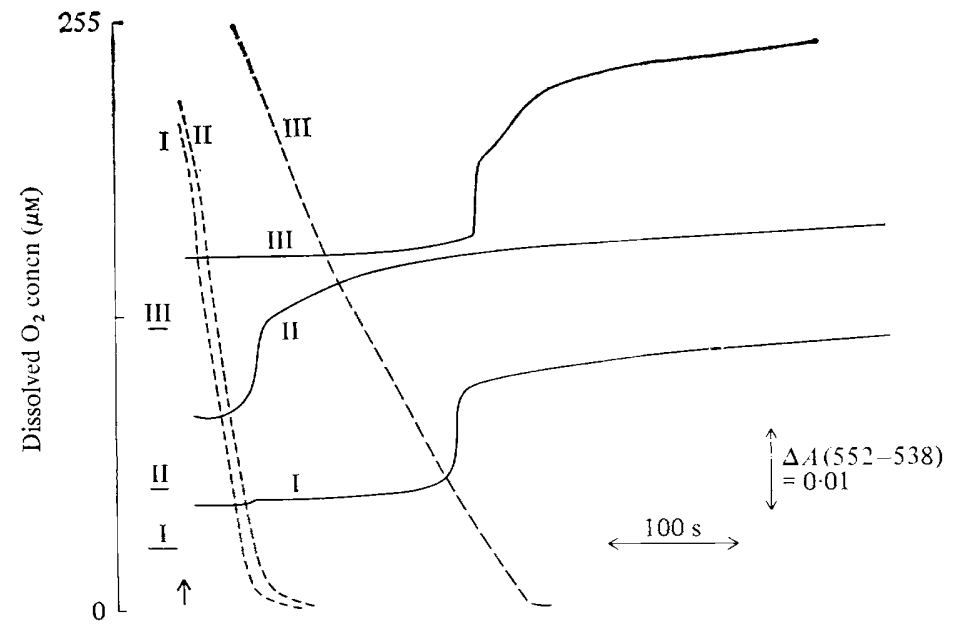

Fig. 5. Reduction of cytochrome $c$ [ $\Delta A$ (552-538)] by formate in extracts of $C$. sputorum subsp. bubulus in the absence (I, III) or presence (II) of catalase $\left(30 \mu \mathrm{g} \mathrm{ml}^{-1}\right)$. Formate (final concentration $7 \mathrm{~mm}$ ) was added at the time indicated by the arrow. The dashed lines represent the $\mathrm{O}_{2}$ consumption. The extracts contained $3.6 \mathrm{mg}$ protein $\mathrm{ml}^{-1}$ (I, II) or $6.8 \mathrm{mg}$ protein $\mathrm{ml}^{-1}$ (III). Organisms were grown in TF medium at a d.o.t. of $2 \mathrm{kPa}$ for $4 \mathrm{~h}$ (I, II) or a d.o.t. of $2 \mathrm{kPa}$ for $2 \mathrm{~h}$ followed by $3 \mathrm{~h}$ at a d.o.t. of $15 \mathrm{kPa}$ (III).

and $429 \mathrm{~nm}$, respectively (Fig. 4). In spite of these differences we believe that both spectra are mainly due to the presence of the same pigment, because in both the supernatant and the pellet fraction, the reaction with $\mathrm{CO}$ measured by the development of the $\gamma$-peak was rather slow. For this reason spectra were recorded $15 \mathrm{~min}$ after $\mathrm{CO}$ was bubbled through the cuvette. Thus, the CO-binding pigment must be a cytochrome of the $c$-type, because only cytochrome $c$ was detected in the supernatant fraction. The shift of the trough in the pellet spectrum to a higher wavelength compared with the trough in the supernatant spectrum might be due to a small amount of another membrane-bound CO-binding pigment, possibly cytochrome $o$. Using the absorption coefficient given by Bartsch (1967) [ $\epsilon$ (peak-to-plateau) $=551 \mathrm{mmol}^{-1} \mathrm{~cm}^{-1}$ per haem group] for a CO-binding cytochrome $c$ and assuming that each CO-binding cytochrome $c$ contains one haem group, it was calculated that 55 to $60 \%$ of the cytochrome $c$ in the pellet fraction and $70 \%$ of the cytochrome $c$ in the supernatant fraction binds CO.

Organisms which had been exposed to a d.o.t. of $15 \mathrm{kPa}$ in a d.o.t.-shift experiment contained $60 \%$ of the cytochrome $c$ and CO-binding pigment present in those grown at a d.o.t. of $2 \mathrm{kPa}$.

\section{Reduction kinetics of cytochrome $c$}

Cytochrome $c$ of TF-grown C. sputorum (d.o.t. $=2 \mathrm{kPa}$ ) was reduced by formate in a stepwise manner (Fig. 5). The first and second plateaux were attributed to the oxidizing action of $\mathrm{O}_{2}$ and $\mathrm{H}_{2} \mathrm{O}_{2}$, respectively (Niekus et al., 1978). The length of the ' $\mathrm{O}_{2}$ ' steady-state equalled the time needed to consume almost all the $\mathrm{O}_{2}$ in the cuvette (Fig. 5). $\mathrm{H}_{2} \mathrm{O}_{2}$ is a product of formate oxidation (see above). After the transition to the state of maximum reduction of cytochrome $c$, presumably when $\mathrm{H}_{2} \mathrm{O}_{2}$ was depleted by the action of cytochrome $c$ peroxidase, the reduction level continued to increase slowly. In extracts from TL-grown organisms another plateau of unknown origin was seen in this part of the curve (Niekus $\epsilon t$ $a l .$, 1978). Formate could reduce about $70 \%$ of the dithionite-reducible cytochrome $c$. In the presence of catalase $\left(30 \mu \mathrm{g} \mathrm{ml}^{-1}\right)$ the duration of the steady-state observed equalled the time necessary for the consumption of $\mathrm{O}_{2}$ from the cuvette (Fig. 5). NADH and NADPH could reduce cytochrome $c$ in an extract of $C$. sputorum by $80 \%$, but NADPH did so much faster than NADH (results not shown). 
Formate reduced both cytochrome $c$ and $b$ in the pellet fraction and cytochrome $c$ in the supernatant fraction obtained after centrifuging an extract of TF-grown cells (d.o.t. $=2$ $\mathrm{kPa}$ ) at $140000 \mathrm{~g}$ for $1.5 \mathrm{~h}$. The reduction level $15 \mathrm{~min}$ after the addition of formate was 70 to $80 \%$ of that with dithionite as reductant. Ascorbate plus TMPD reduced cytochrome $c$ in both fractions (maximum reduction, about $50 \%$ ), but could not reduce cytochrome $b$ in the pellet fraction.

Extracts from organisms which had been exposed to a d.o.t. of $15 \mathrm{kPa}$ for $3 \mathrm{~h}$ in a d.o.t.shift experiment were still able to reduce cytochrome $c$ in the presence of formate. The ' $\mathrm{O}_{2}$ ' and ' $\mathrm{H}_{2} \mathrm{O}_{2}$ ' steady-states were not separately visible in this case (Fig. 5). When $\mathrm{O}_{2}$ was depleted from the cuvette, cytochrome $c$ passed into the state of maximum reduction. Catalase did not reduce the length of the steady-state (result not shown).

\section{DISCUSSION}

The addition of formate to the growth medium improves growth of $C$. sputorum subsp. bubulus under a reduced oxygen atmosphere but L-lactate is a more efficient energy source (Niekus et al., 1977; de Vries et al., 1980). Laanbroek et al. (1978) reported that a free-living Campylobacter species grew with formate and $\mathrm{O}_{2}$ in a mineral medium supplemented with acetate as carbon source. On the other hand, Lecce (1958) found that $0.5 \%$ formate completely inhibited the growth of five Vibrio fetus strains in heart infusion broth in a candle jar [Vibio fetus was later renamed Campylobacter fetus by Sebald \& Véron (1963)].

The scheme of formate oxidation in C. sputorum (see Introduction) proposes electron transport from formate via cytochrome $c$ to $\mathrm{O}_{2}$ or $\mathrm{H}_{2} \mathrm{O}_{2}$ produced in the formate oxidase reaction. Thus, both cytochrome oxidase and cytochrome peroxidase are considered to play a role in the terminal electron transfer from cytochrome $c$. The separate contribution of each in situ, when C. sputorum is growing at a favourable d.o.t., is still unknown. The presence of cytochrome $c$ peroxidase in $C$. sputorum subsp. bubulus has been shown in this study. The NADPH peroxidase activity also found could be mediated by cytochrome $c$, because $C$. sputorum possessed an active NADPH : cytochrome $c$ oxidoreductase. Evidence for the presence of a conventional cytochrome oxidase in C. sputorum is poor. Ascorbate-TMPD oxidase activity is widely taken as a measure of oxidase activity (Jurtshuk et al., 1975) and ascorbate-TMPD oxidase was found in TF-grown organisms (Table 1). Less was present in TL-grown organisms (H. G. D. Niekus, unpublished result). Ascorbate plus TMPD could reduce cytochrome $c$ partly, so at least some of the cytochrome $c$ present in $C$. sputorum has a high midpoint potential. Spectral evidence for the presence of a cytochrome oxidase in C. sputorum was only indirect. The large peaks of the CO-binding cytochrome $c$ could have masked any clear contribution to the (reduced-plus-CO minus reduced) difference spectrum by small amounts of cytochrome oxidases present. Hoffman et al. (1979) detected small amounts of cytochromes $o$ and $d$ in C. fetus subsp. jejuni.

When the cytochrome $c$ reduction by formate was followed, stepwise kinetics were observed (Fig. 5). During the first stage, $\mathrm{O}_{2}$ was consumed in the formate oxidase reaction producing $\mathrm{H}_{2} \mathrm{O}_{2}$. The appearance of a separate ' $\mathrm{O}_{2}$ ' steady-state suggests that $\mathrm{O}_{2}$ at the same time functioned as terminal electron acceptor in the cytochrome oxidase reaction. Catalase prevented the accumulation of $\mathrm{H}_{2} \mathrm{O}_{2}$ and, by doing so, the appearance of a ' $\mathrm{H}_{2} \mathrm{O}_{2}$ ' steadystate. Catalase was without effect in an extract obtained from organisms that had been exposed to a d.o.t. of $15 \mathrm{kPa}$ during growth. Evidently, no or little $\mathrm{H}_{2} \mathrm{O}_{2}$ accumulated. This is explained by the finding that the loss of activity of the $\mathrm{H}_{2} \mathrm{O}_{2}$-producing system (formate oxidase) after exposure to a high d.o.t. was much greater than that of the $\mathrm{H}_{2} \mathrm{O}_{2}$-eliminating system (cytochrome $c$ peroxidase) (Table 1).

Most enzyme activities were lowered after exposure to a d.o.t. of $15 \mathrm{kPa}$. Formate oxidase and formate dehydrogenase were particularly sensitive. The loss of formate oxidase activity in extracts correlated well with the sharp decrease in the potential respiration rate of 
organisms after the d.o.t. was raised from 2 to $15 \mathrm{kPa}$. Catalase or superoxide dismutase could not prevent the growth inhibitory action of $15 \mathrm{kPa} \mathrm{O}$ or its effect on the rate of formate consumption and the potential respiration rate. This rules out the possibility that auto-oxidation of medium components is involved in the detrimental effect of a high d.o.t. The aerotolerance of organisms growing in TF medium did not differ from the aerotolerance of those growing in TL medium. The critical d.o.t. above which growth was impaired was in both cases approximately $10 \mathrm{kPa}$. Evidently, formate in the growth medium was tolerated by $C$. sputorum at a favourable d.o.t. despite $\mathrm{H}_{2} \mathrm{O}_{2}$ production. $\mathrm{H}_{2} \mathrm{O}_{2}$, which is a product as well as an inhibitor of formate oxidase, could play an important role in the oxygen sensitivity of $C$. sputorum. It is proposed that, when the d.o.t. is raised to a high level, the $\mathrm{H}_{2} \mathrm{O}_{2}$ produced cannot be immediately disposed of and exerts its harmful effect nearby on the formate-oxidizing system. The low affinity of formate oxidase for $\mathrm{O}_{2}$ is consistent with this hypothesis. Because of the initial increase in the $\mathrm{O}_{2}$ consumption rate, the $\mathrm{H}_{2} \mathrm{O}_{2}$-producing and $\mathrm{H}_{2} \mathrm{O}_{2}$-eliminating systems are no longer well-balanced after the shift to a high d.o.t. The respiratory activity with formate was more susceptible to a d.o.t. of $15 \mathrm{kPa}$ when the organisms were grown in TF medium than in the absence of formate. This can be related to the increased rate of respiration and thus of $\mathrm{H}_{2} \mathrm{O}_{2}$ production in TF medium. Besides $\mathrm{H}_{2} \mathrm{O}_{2}$, a low superoxide dismutase content has been implicated in the microaerophilic nature of C. sputorum subsp. bubulus (Niekus et al., 1978). To be more certain of the role of $\mathrm{H}_{2} \mathrm{O}_{2}$ we need to know whether $\mathrm{H}_{2} \mathrm{O}_{2}$ and/or formate are common intermediates in the metabolism of $C$. sputorum growing aerobically in the absence of formate. It has been reported earlier that $\mathrm{H}_{2} \mathrm{O}_{2}$ is a product of L-lactate oxidation (Niekus et al., 1978). Further characterization of the formate oxidase may yield a better insight into oxygen metabolism in this organism.

\section{REFERENCES}

Bartsch, R. G. (1967). Spectroscopic properties of purified cytochromes of photosynthetic bacteria. In Bacterial Photosynthesis, pp. 475-494. Edited by H. Gest, L. P. Vernon \& A. San Pietro. Antioch, Ohio: Antioch Press.

Ellfolk, N. \& Sorninen, R. (1970). Pseudomonas cytochrome $c$ peroxidase. I. Purification procedure. Acta chemica scandinavica 24, 2126-2136.

Hoffman, P. S., Krieg, N. R. \& Smibert, R. M. (1979). Studies of the microaerophilic nature of Campylobacter fetus subsp. jejuni. I. Physiological aspects of enhanced aerotolerance. Canadian Journal of Microbiology 25, 1-7.

JACOBS, N. J. \& Wolin, M. J. (1963). Electron transport system of Vibrio succinogenes. II. Inhibition of electron transport by 2-heptyl-4-hydroxyquinoline $N$-oxide. Biochimica et biophysica acta 69 , 29-39.

Jurtshuk, P., JR, Mueller, T. J. \& Acord, W. C. (1975). Bacterial terminal oxidases. CRC Critical Reviews in Microbiology 3, 399-468.

Kröger, A. \& INNERHOFER, A. (1976). The function of the $b$ cytochromes in the electron transport from formate to fumarate of Vibrio succinogenes. European Journal of Biochemistry 69, 497-506.

LaAnbroek, H. J., Stal, L. J. \& Veldkamp, H. (1978). Utilization of hydrogen and formate by Campylobacter spec. under aerobic and anaerobic conditions. Archives of Microbiology 119, 99-102.

LANG, E. \& LANG, H. (1972). Spezifische Farbreaktion zum direkten Nachweis der Ameisensäure. Zeitschrift für analytische Chemie 260, 8-10.
LECCE, J. G. (1958). Some biochemical characteristics of Vibrio fetus and other related vibrios isolated from animals. Journal of Bacteriology 76, 312316.

Loesche, W. J., Gibbons, R. J. \& Socransky, S. S. (1965). Biochemical characteristics of Vibrio sputorum and relationship to Vibrio bubulus and Vibrio fetus. Journal of Bacteriology 89, 11091116.

McCord, J. M. \& Fridovich, I. (1969). Superoxide dismutase. An enzymic function for erythrocuprein (hemocuprein). Journal of Biological Chemistry 244, 6049-6055.

Niekus, H. G. D., de Vries, W. \& Stouthamer, A. H. (1977). The effect of different dissolved oxygen tensions on growth and enzyme activities of Campylobacter sputorum subspecies bubulus. Journal of General Microbiology 103, 215-222.

Niekus, H. G. D., Wouters, C. H., DE VRies, W. \& Stouthamer, A. H. (1978). Superoxide dismutase and hydrogen peroxide formation in Campylobacter sputorum subspecies bubulus. Archives of Microbiology 119, 37-42.

Sebald, M. \& Véron, M. (1963). Teneur en bases de l'ADN et classification des vibrions. Annales de l'Institut Pasteur 105, 897-910.

Smibert, R. M. (1978). The genus Campylobacter. Annual Review of Microbiology 32, 673-709.

Stouthamer, A. H., de VRIES, W. \& Niekus, H. G. D. (1979). Microaerophily. Antonie van Leeuwenhoek 45, 5-12.

de Vries, W., NieKus, H. G. D., Boellatard, M. \& 
Stouthamer, A. H. (1980). Growth yields and energy generation by Campylobacter sputorum subspecies bubulus during growth in continuous culture with different hydrogen acceptors. Archives of Microbiology 124, 221-227.
Yonetani, T. \& RaY, G. S. (1965). Studies on cytochrome oxidase. VI. Kinetics of the aerobic oxidation of ferrocytochrome $c$ by cytochrome oxidase. Journal of Biological Chemistry 240, 3392-3398. 